\title{
PEMBERDAYAAN KADER POSYANDU TERHADAP KEJADIAN STUNTING DI WILAYAH KERJA KELURAHAN SUNGAI MIAI KOTA BANJARMASIN
}

\author{
Agus Jalpi, Achmad Rizal, dan Fahrurazi \\ Fakultas Kesehatan Masyarakat, Universitas Islam Kalimantan \\ Email: agusjalpi.fkmuniska@gmail.com
}

\begin{abstract}
ABSTRAK
Prevalensi kejadian stunting bayi berusia dibawah lima tahun (balita) di Indonesia pada tahun 2015 sebesar 36,4\% (Penentuan Status Gizi, 2017), dimana balita sendiri mengalami stunting sebesat $26,6 \%$ dengan rincian kategori sangat pendek $9,8 \%$, dan pendek sebesar $19,8 \%$. Solusi yang ditawarkan Untuk meningkatkan status gizi pada anak supaya memperoleh asupan gizi baik secara kuantitas dan kualitas serta mencegah terjadinya stunting maka diperlukan peranan ibu balita, petugas kesehatan dalam hal ini kader posyandu. Dalam usaha untuk meningkatkan kesadaran masyarakat utamanya tentang pentingnya pengetahuan gizi dan keterampilan pengolahan pangan (makanan) maka tindakan yang akan dilakukan adalah melakukan advokasi, base line data, pemberdayaan masyarakat dan kader posyandu serta evaluasi dan monitoring. Khalayak sasaran dalam kegiatan PPM ini adalah Ibu Rumah Tangga yang memiliki balita yang status gizi kurang dan kader posyandu sebanyak 38 orang di posyandu dengan rincian 20 ibu balita dan 8 kader posyandu. Metode pendekatan yang ditawarkan untuk mendukung realisasi program pengabdian kepada masyarakat melalui media promosi kesehatan bagi kader posyandu di kelurahan Sungai Miai. Kegiatan monitoring dilakukan pada tanggal 2 Maret 2020 yang bertujuan untuk mengevaluasi status gizi dalam hal peningkatan berat badan pada balita gizi kurang yang sudah mendapatkan proses pendampingan dan pengolahan sop bagi balita. Evaluasi dilakukan dengan membandingkan selera makan anak sebelum dan setelah pemberian produk. Monitoring dilakukan dengan menimbang balita yang sudah mendapatkan produk intervensi. Hasil penimbangan tersebut didapatkan bahwa berat badan balita sebelum dan setelah pemberian produk makanan adalah rata-rata berat badan sebelum pemberian produk adalah $13,37 \mathrm{~kg}$, dan setelah pemberian produk rata-rata mengalami kenaikan sekitar $0,86 \mathrm{~kg}$ sehingga rata-rata berat badan balita setelah pemberian adalah $13,23 \mathrm{~kg}$. kenaikan ini cukup signifikan karena secara teori kenaikan berat badan selama satu bulan minimal mendekati $1 \mathrm{~kg}$. Diharapkan ibu senantiasa aktif ke posyandu balita guna memantau tumbuh kembang anak dan aktif mencari informasi terkait pola asuh anak balitanya.
\end{abstract}

Kata Kunci : Pemberdayaan Kader Posyandu, Kejadian Stunting

PENDAHULUAN

\section{Analisis Situasi}

Masa balita sering dinyatakan sebagai masa kritis dalam rangka mendapatkan sumber daya manusia yang berkualitas dan merupakan masa growth spurth dimana terjadi pertumbuhan dan perkembangan otak yang optimal. Jika masalah gangguan gizi pada balita dibiarkan akan berakibat fatal, Indonesia akan kehilangan generasi penerus bangsa 
yang berkualitas (loss generation). Masalah kurang gizi pada balita sudah terjadi sejak lama dan belum dapat terselesaikan (Raodhah, dkk., 2015).

Berdasarkan data Riskesdas 2013 prevalensi berat-kurang (underweight) pada tahun 2013 adalah $19,6 \%$ terdiri dari 5,7 \% gizi buruk dan 13,9\% gizi kurang. Jika dibandingkan dengan angka prevalensi nasional tahun $2007(18,4 \%)$ dan tahun $2010(17,9 \%)$ terlihat meningkat. Untuk mencapai sasaran MDG's tahun 2015 yaitu 15,5\% maka prevalensi gizi buruk-kurang secara nasional harus diturunkan sebesar 4,1\% dalam periode 2013 sampai 2015.

Salah satu penyebab gizi kurang pada balita adalah tidak cukup mendapat makanan bergizi seimbang yang disebabkan rendahnya pengetahuan keluarga tentang gizi dan cara pengolahannya. Perbaikan gizi pada balita, tidak cukup hanya dengan memberikan PMT saja, tetapi juga dengan peningkatan pengetahuan gizi keluarga. Meningkatnya pengetahuan dan metode pengolahan makanan sebagai intervensi boleh jadi akan diikuti dengan perubahan perilaku.

Penyuluhan gizi dengan metode ceramah disertai media poster dan leaflet dan cara pembuatan variasi pengolahan merupakan salah satu pendekatan pembelajaran dengan memberi seperangkat pengetahuan dan keterampilan yang diperlukan pada sasaran agar mampu menentukan pilihan perilaku yang tepat untuk meningkatkan status gizi balitanya ibu yang mempunyai peran yang sangat penting dalam pertumbuhan balita terutama dalam hal pemberian makanan maka perlu diberikan proses pendampingan dan penyuluhan secara berkelanjutan dalam hal pengetahuan gizi dan pengolahan makanan dengan berbagai variasi sehingga dapat meningkatkan status gizi anak balitanya serta bisa memberikan nilai ekonomi dalam keluarganya. Untuk mengatasi masalah tersebut diperlukan usaha yang cepat untuk memperbaiki makanan anak agar bisa mendapatkan sumber protein yang baik dengan harga yang murah dan mudah diperoleh khususnya bahan lokal di daerah masing-masing (Raodhah, dkk., 2015).

Masalah gizi kurang sangan erat kaitannya dengan terjadinya stunting pada balita. Salah satu faktor yang berperan aktif dalam mendeteksi dini masalah adalah peran seorang ibu balita dan kader. Ibu balita berperan langsung 
dalam hal pengolahan makanan pada balita. Kader adalah tenaga sukarela yang dipilih oleh masyarakat dan bertugas mengembangkan masyarakat. disini kader berperan aktif dalam penimbangan balita, pencatatan/pengisian KMS, keterampilan dalam interpretasi hasil penimbangan, karena kader kesehatan mempunyai peran besar dalam upaya meningkatkan kemampuan masyarakat menolong dirinynya untuk mencapai derajat kesehatan yang optimal sehingga dapat dilakukan pelatihan kader.

Pengetahuan tentang makanan jajanan menjadi sangat penting dimiliki orang tua yang mana harus diterapkan kepada anak. Peranan dan andil guru juga sangat dibutuhkan siswa dalam melakukan pemilihan makanan jajanan yang diperjual belikan di lingkungan sekolah (Rizal, 2016).

Menyadari akan arti pentingnya peran aktif masyarakat dalam menunjang keberhasilan pembangunan dalam bidang kesehatan diperlukan adanya agen-agen pembangunan yang dapat menumbuhkan kesadaran masyarakat untuk berpartisipasi dalam pembangunan. Partisipasi masyarakat dalam pembangunan kesehatan yang mempunyai peran besar salah satunya adalah peran kader posyandu. Dalam hal ini peran yang besar adalah peran kader Posyandu yang secara langsung berhadapan dengan berbagai permasalahan kemasyarakatan termasuk masalah kesehatan yang dihadapi oleh masyarakat (Raodhah, dkk., 2015).

Salah satu tercapainya indikator cakupan partisipasi ibu guna mendapatkan informasi dan ajakan yang dilakukan oleh kader posyandu melalui media promosi kesehatan dalam mengatasi masalah kasus preeklamsi ibu melahirkan (Rizal, dkk, 2018).

Kota Banjarmasin memiliki 26 unit Puskesmas. Puskesmas ini memiliki sekian banyak posyandu, diantaranya Posyandu Pratama jumlahnya 5 unit, target kemandiriannya 16 yang tercapai 15 (94\%), Posyandu Madya jumlahnya 20 unit, target kemandiriannya 6 yang tercapai 5 (83\%), dan Posyandu Purnama jumlahnya 1 unit, target kemandiriannya 3 yang tercapai 2 $(67 \%)$.

Kader kesehatan bertanggung jawab terhadap masyarakat setempat serta pimpinan-pimpinan yang ditunjuk oleh pusat-pusat pelayanan kesehatan. Diharapkan mereka dapat melaksanakan petunjuk yang diberikan oleh para 
pembimbing dalam jalinan kerja dari sebuah tim kesehatan.

Berdasarkan hal diatas maka kami bermaksud akan mengadakan pemberdayaan masyarakat melalui pelatihan kader posyandu dan pembentukan kelompok peduli gizi serta pelatihan pengolahan makanan pada balita guna pencegahan kejadian stunting.

\section{Perumusan Masalah}

a. Praktik pemberian makan terutama dalam hal pengolahan makanan yang baik dan tepat sangat penting untuk kelangsungan hidup, pertumbuhan, perkembangan, kesehatan dan gizi bayi dan anak. Pada usia balita sebagian besar anak tidak mendapat asupan makan dalam jumlah yang cukup baik dari segi kuantitas maupun kualitas. Jika pada masa balita tidak memperoleh cukup gizi, maka akan mengakibatkan gangguan pertumbuhan dan kurang gizi. Oleh karena itu megatasi masalah

kekurangan gizi maka diperlukan perbaikan pada kuantitas dan kualitas asupan makan. Salah satu faktor yang berperan aktif dalam mendeteksi dini masalah adalah peran seorang ibu balita dan kader.

b. Ibu balita berperan langsung dalam hal pengolahan makanan pada balita. Kader adalah tenaga sukarela yang dipilih oleh masyarakat dan bertugas mengembangkan masyarakat. disini kader berperan aktif dalam penimbangan balita, pencatatan/pengisian KMS, keterampilan dalam interpretasi hasil penimbangan, karena kader kesehatan mempunyai peran besar dalam upaya meningkatkan kemampuan masyarakat menolong dirinynya untuk mencapai derajat kesehatan yang optimal sehingga dapat dilakukan pelatihan kader. Menyadari akan arti pentingnya peran aktif masyarakat dalam menunjang keberhasilan pembangunan dalam bidang kesehatan diperlukan adanya agenagen pembangunan yang dapat menumbuhkan kesadaran masyarakat untuk berpartisipasi dalam pembagunan.

c. Partisipasi masyarakat dalam pembangunan kesehatan yang mempunyai peran besar salah satunya adalah peran kader posyandu. Dalam hal ini peran yang besar adalah peran kader Posyandu 
yang secara langsung berhadapan dengan berbagai permasalahan kemasyarakatan termasuk masalah kesehatan yang dihadapi oleh masyarakat. Bertitik tolak dari hal tersebut diatas maka kami bermaksud akan mengadakan pemberdayaan masyarakat dan Kader Posyandu melalui pelatihan kader posyandu dan pembentukan kelompok peduli gizi serta pelatihan pengolahan makanan pada balita.

\section{Solusi Yang Dilaksanakan}

Untuk meningkatkan status gizi pada anak supaya memperoleh asupan gizi baik secara kuantitas dan kualitas serta mencegah terjadinya stunting maka diperlukan peranan ibu balita, petugas kesehatan dalam hal ini kader posyandu. Dalam usaha untuk meningkatkan kesadaran masyarakat utamanya tentang pentingnya pengetahuan gizi dan keterampilan pengolahan pangan (makanan) maka tindakan yang akan dilakukan adalah melakukan advokasi, base line data, pemberdayaan masyarakat dan kader posyandu serta evaluasi dan monitoring. Adapun bagan alur kegiatan yang akan dilakukan adalah sebagai berikut:

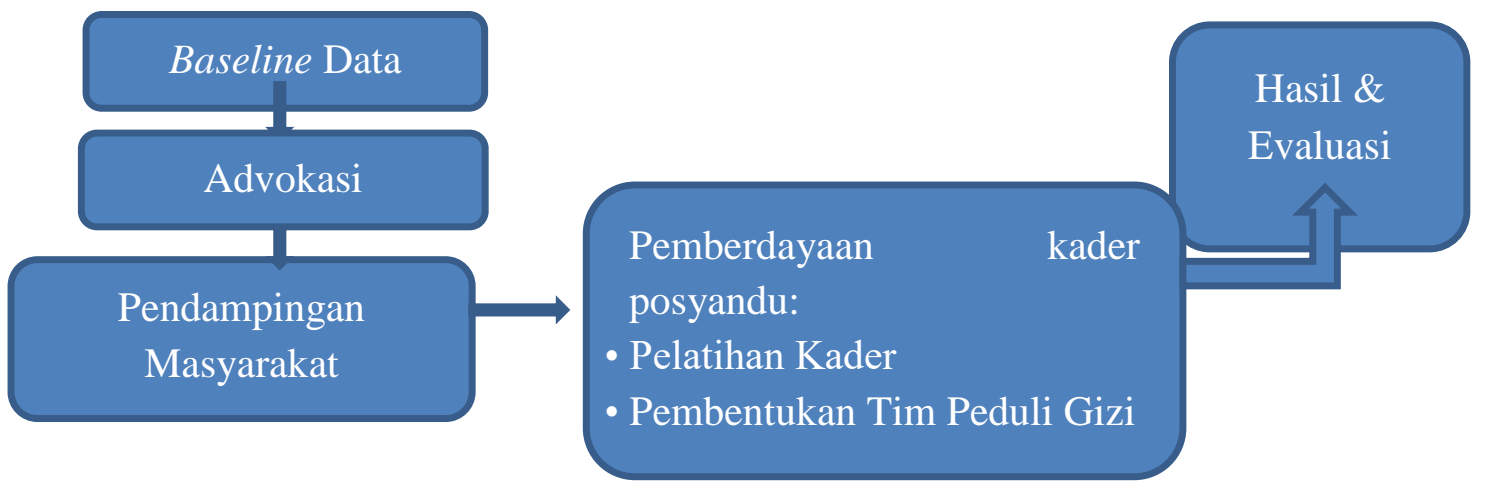

Gambar 1. Bagan Kegiatan P2M

\section{METODE PELAKSANAAN}

\section{KEGIATAN}

\section{Metode Pelaksanaan Kegiatan}

Metode pendekatan yang ditawarkan untuk mendukung realisasi program pengabdian kepada masyarakat melalui media promosi kesehatan bagi kader posyandu di kelurahan Sungai Miai adalah sebagai berikut:

1. Wawancara langsung kepada para kader posyandu kemudian diidentifikasi permasalahan yaitu pencegahan stunting.

2. Pelatihan teoritis (metode kelas) 
teknik penyuluhan dan promosi kesehatan.

3. Pelatihan dalam hal metode promosi kesehatan bagi kader posyandu secara profesional.

4. Praktek/demontrasi (mengolah makanan bergizi) langsung yang dilaksakanakan oleh kader posyandu dengan bimbingan tim pengusul pengabdian kepada masyarakat.

5. Pengadaan alat berupa media promosi kesehatan berupa leaflet/poster dengan desain yang menarik dan media lainnya.

\section{KHALAYAK SASARAN}

Yang menjadi khalayak sasaran dalam kegiatan PPM ini adalah Ibu Rumah Tangga yang memiliki balita yang status gizi kurang dan kader posyandu sebanyak 28 orang di posyandu dengan rincian $20 \mathrm{ibu}$ balita dan 8 kader posyandu.

\section{HASIL PELAKSANAAN KEGIATAN Pra dan Hasil Kegiatan}

Kegiatan pengabdian masyarakat dilaksanakan selama 4 (empat) bulan, dengan rangkaian kegiatan sebagai berikut:

\section{Pra Kegiatan}

Pra kegiatan dilaksanakan bertujuan untuk melakukan penyusunan proposal yang dilaksanakan bulan Oktober 2019 kegiatan yang diawali dengan melakukan diskusi dengan tim pengabdian untuk menentukan tema dari kegiatan selanjutnya melakukan pengumpulan referensi dalam rangka penyusunan proposal pengabdian.

\section{Baseline Data}

Kegiatan baseline data dilakukan selama 2 hari dari tanggal 30 - 31 Januari 2020. Tujuan baseline data adalah untuk memperoleh data tentang karakteristik balita dan keluarganya serta melakukan screening untuk balita yang dicurigai mengalami gizi kurang. Hasil dari baseline data berikut adalah: 
Tabel 5.1

Distribusi Responden Berdasarkan Karakteristik Responden di Posyandu Kota Banjarmasin Tahun 2019

\begin{tabular}{lrc}
\hline \multicolumn{1}{c}{ Karakteristik Responden } & n (20) & \% \\
\hline Umur ibu (Tahun) & 2 & 10,0 \\
a. $<$ 20 & 13 & 65,0 \\
b. $20-30$ & 5 & 25,0 \\
c. $>$ 30 & 15 & \\
\hline Pendidikan Ibu & 2 & 75,0 \\
a. SD & 2 & 10,0 \\
b. SMP & 1 & 10,0 \\
c. SMA & & 0,5 \\
d. Diploma & 19 & \\
Pekerjaan Ibu & 1 & 95,0 \\
a. IRT & & 5,0 \\
b. Wiraswasta & 15 & \\
\hline Jumlah Anggota Keluarga & 5 & 75,0 \\
a. 3-5 orang & & 25,0 \\
b. $>$ orang & & \\
\hline
\end{tabular}

Karakteristik responden berdasarkan usia menunjukkan bahwa lebih banyak responden yang berada pada rentang usia 20-30 tahun sebanyak 13 orang $(65,0 \%)$ dan Usia $>30$ tahun sebanyak 5 orang $(25,0 \%)$, sedangkan usia $<20$ tahun sebanyak 2 orang (10,0\%). Menurut Undang-Undang Tenaga Kerja No. 13 Tahun 2003, usia produktif angkatan kerja yaitu antara 15-64 tahun. Sehinggga dari hasil baseline diketahui bahwa seluruh responden termasuk dalam usia produktif.

Usia produktif memiliki kaitan terhadap kesempatan mengasuh anak terutama dalam hal pengolahan makanan. Fahmi (2010) dalam bukunya yang berjudul Menit
Untuk Anakku (2010:130-131) mengungkapkan bahwa produktifitas dalam mengasuh anak maupun balita ada batasnya. Sementara yang dibutuhkan adalah memanfaatkan waktu sebaik-baiknya saat usia produktif dalam mengasuh anak dan balita itu masih orang tua (ibu) jalankan. Selama usia produktif itu orang tua (ibu) masih terus mengasah kemampuan dalam mengasuh termasuk dalam mengolah makanan. Karakteristik responden berdasarkan tingkat pendidikan diperoleh hasil bahwa jumlah responden yang tingkat pendidikannya SD lebih banyak yaitu 15 orang $(75,0 \%)$ dibandingkan dengan yang pendidikannya hanya 
sampai SMA dan yang lulus PT. Latar belakang pendidikan orang tua memegang peranan yang sangat penting dalam kehidupan berkeluarga semakin tinggi tingkat pendidikan ayah dan ibu anak diharapkan pengetahuan tentang gizi dan kesehatan anak balitanya akan lebih baik. Sehingga bagi para orang tua (ibu) memungkinkan rajin mencari serta mengakses informasi tentang gizi dan kesehatan lebih baik dan akan berimplikasi pada konsumsi pangan melalui cara pemilihan bahan pangan dan pengolahan makanan yang sesuai dengan kebutuhan anak maupun balitanya.

Karakteristik orang tua berdasarkan pekerjaan diketahui lebih banyak yang tidak bekerja atau berperan sebagai Ibu Rumah Tangga
(IRT) yaitu 19 orang (95\%). Bauer (2006) dalam Adelia (2012) menjelaskan bahwa ibu yang tidak bekerja memiliki waktu lebih banyak yang dapat dihabiskan dengan anak maupun balita mereka setiap harinya. Dalam hal ini orang tua (ibu) dapat mengatur pola makan anak, melakukan variasi pengolahan makanan, mengatur waktu istirahat dan bermain anak balitanya serta melatih dan mendidik anak sehingga perkembangan anak lebih baik dibandingkan dengan ibu yang bekerja. Berdasarkan data yang diperoleh menunjukkan bahwa sampel dengan jumlah anggota keluarga 3-5 orang terbanyak adalah 15 orang $(75,0 \%)$, dan anggota keluarga $>5$ orang sebanyak 5 orang $(25 \%)$.

Tabel 5.2

Distribusi responden berdasarkan karakteristik balita di Posyandu Kota Banjarmasin Tahun 2019

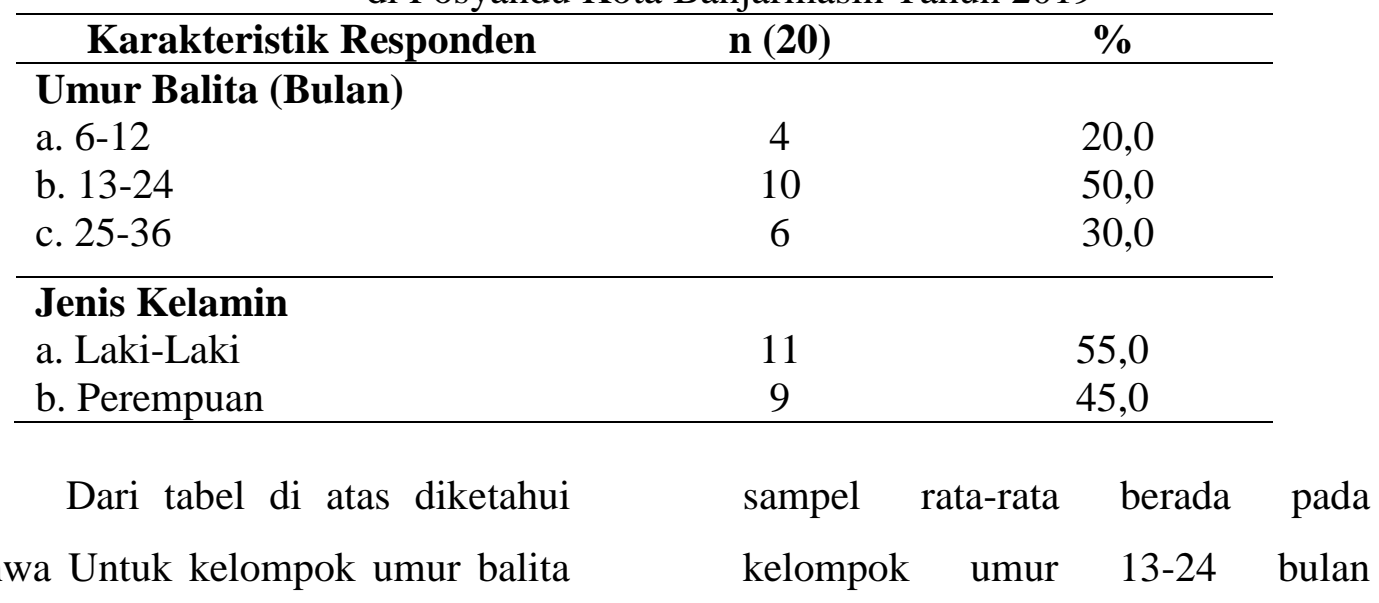


sebanyak 10 anak (50\%), pada kelompok umur 25-36 bulan sebanyak 6 anak (30\%), sedangkan pada kelompok umur 2-12 bulan sebanyak 4 anak (20\%). Untuk jenis kelamin balita perempuan sebanyak 11 anak (55\%) lebih banyak dari balita jenis kelamin laki-laki 9 anak $(45 \%)$.

\section{Advokasi}

Sebelum dilakukan kegiatan advokasi terlebih dahulu dilakukan pra advokasi yang dilaksanakan pada tanggal dengan melakukan pertemuan dengan kepala posyandu di Keluarahan Sungai Miai untuk membicarakan tentang kegiatan yang akan dilaksanakan selama pengabdian dan kondisi yang terkait di lapangan. Setelah melakukan kegiatan pra advokasi selanjutnya dilakukan kegiatan advokasi pada tanggal 21-22 Oktober 2019 yang melibatkan tokoh masyarakat, tokoh agama, kader posyandu dan tenaga kesehatan di posyandu Kelurahan Sungai Miai kota Banjarmasin.

Tujuan umum kegiatan advokasi adalah memberikan sosialisasi secara umum aktivitas kampus dan kerjasama yang akan dijalin dengan masyarakat dan untuk memperoleh dukungan dan komitmen serta kesamaan presepsi dalam upaya perbaikan gizi masyarakat terutama balita. Adapun target yang ingin dicapai yakni kesadaran masyarakat akan pentingnya gizi, perubahan perilaku masyarakat menuju gizi seimbang dengan peningkatan keterampilkan dalam mengolah makanan, perbaikan status gizi masyarakat.

Indikator untuk melihat keberhasilan advokasi ini, yakni berupa keterlibatan, dukungan dan kesinambungan yang diberikan oleh sasaran advokasi dalam hal ini masyarakat terutama kader posyandu dan ibu balita dimana pada saat kegiatan berlangsung khalayak sasaran sekitar $95 \%$ hadir dalam kegiatan tersebut dan memberikan tanggapan yang positif dan mengharapkan kesinambungan kegiatan ini.

\section{Pendampingan Tim}

Kegiatan ini dilaksanakan selama (3 hari) dengan khalayak sasaran adalah balita yang mengalami status gizi kurang. Tujuan kegiatan ini adalah pengenalan dan aplikasi produk dengan output perbaikan status gizi 
balita. Pengenalan produk dilakukan dengan cara memberikan informasi kepada orang tua balita yang mengalami status gizi kurang tentang manfaat dan kandungan gizi yang terdapat dalam produk pengolahan makanan sehingga dapat memperbaiki status gizi balita yang mengalami gizi kurang. Setelah diberikan informasi tentang produk pengolahan makanan selanjutnya dilakukan proses pendampingan dan pemberian produk kepada balita gizi kurang selama 4 hari dari tanggal 9 Desember sampai dengan tanggal 12 Desember 2019

\section{Pemberdayaan Kader}

Kegiatan pemberdayaan kader posyandu dilakukan selama 2 hari dengan kegiatan sebagai berikut:

\section{a. Pelatihan Kader}

Kegiatan ini dilaksanakan pada tanggal 6 sampai 7 Januari 2020. Peserta adalah kader posyandu sebanyak 8 orang. Pada Kegiatan ini peserta mendapatkan resep pembuatan sayur sop ayam. Materi dalam pelatihan ini adalah bahan-bahan dan cara pembuatan sayur sop dengan metode pelatihan ceramah, diskusi dan simulasi (demonstrasi).

Dalam praktek pembuatan nugget tersebut bahan dan alat disediakan oleh pelaksana (TIM pengabdian Masyarakat). Alat yang dipakai adalah alat yang sifatnya umum dan sederhana sehingga diasumsikan dimiliki oleh semua keluarga.

Tabel 3

Alat-Alat Pembuatan Sayur Sop Ayam

\begin{tabular}{cll}
\hline No. & \multicolumn{1}{c}{ Nama Alat } & \multicolumn{1}{c}{ Kegunaan } \\
\hline 1. & Kompor Gas & Memasak \\
2. & Panci & Mengukus \\
3. & Wajan & Menumis bumbu sop \\
4. & Sendok & Mengaduk \\
5. & Pisau & Memotong \\
6. & Talenan & Alas motong \\
\hline
\end{tabular}

Tabel 4

Bahan- Bahan Pembuatan Sayur Sop Ayam

\begin{tabular}{cll}
\hline No. & \multicolumn{1}{c}{ Jenis Bahan } & \multicolumn{1}{c}{ Volume } \\
\hline 1. & Ayam & $1 / 2$ ekor \\
2. & Kentang ukuran sedang & $2 \mathrm{bh}$ \\
3. & Wortel & $1 \mathrm{bh}$ \\
4. & Kol, daun bawang, selederi & Secukupnya
\end{tabular}


5. Tomat

6. Bumbu sop bubuk

7. Bawang merah putih

9. Royco

8. Bawang goreng

\section{b. Pembentukan Kelompok Peduli}

\section{Gizi}

Kegiatan ini dilaksanakan

pada tanggal 8 Februari 2020

yang khalayak sasaran adalah

kader posyandu dan yang hadir sebanyak 8 orang $(100 \%)$ sesuai dengan yang diharapkan. Tujuan kegiatan ini adalah diharapakan agar adanya SDM (kader posyandu) yang siap mengontrol, mengukur status gizi dan berperan aktif dalam penimbangan balita, pencatatan/pengisian KMS, keterampilan dalam interpretasi hasil penimbangan, dan memberikan edukasi tentang pengolahan makanan. Karena kader kesehatan mempunyai peran besar dalam upaya meningkatkan kemampuan masyarakat menolong dirinya untuk mencapai derajat kesehatan yang optimal sehingga dibentuklah kelompok peduli gizi. Kelompok peduli gizi ini diharapak kader bisa menjadi fasilitator dalam kesinambungan
2 bj

Secukupnya

7-8 siung, 4-5 siung

Secukupnya

Secukupnya

program kegiatan ini seperti dalam hal pemberian produk.

\section{c. Pendampingan Oleh Kader}

$$
\text { Setelah dilakukan }
$$

pelatihan kader dan pembentukan kelompok peduli gizi maka selanjutnya kader melakukan pendampingan terhadap balita yang mengalami status gizi kurang selama 3 hari dari tanggal 24-26 Februari 2020 sebagai lanjutan dari kegiatan pendampingan oleh tim sehingga diharapkan ada perbaikan status gizi pada balita tersebut selama mendapatkan pendampingan produk baik dari pendampingan tim pengabdian maupun dari pendampingan kader.

d. Pemberdayaan masyarakat Melalui Pelatihan Ibu Balita

Gerakan pemberdayaan masyarakat merupakan suatu upaya dalam peningkatan kemampuan masyarakat guna mengangkat harkat hidup, martabat dan derajat kesehatannya. Peningkatan 
keberdayaan berarti peningkatan kemampuan dan kemandirian masyarakat agar dapat mengembangkan diri dan memperkuat sumber daya yang dimiliki untuk mencapai kemajuan. Gerakan pemberdayaan masyarakat juga merupakan cara untuk menumbuhkan dan mengembangkan norma yang membuat masyarakat mampu untuk berperilaku hidup bersih dan sehat. Strategi ini tepatnya ditujukan pada sasaran primer agar berperan serta secara aktif (Supardan, 2013).

Dalam kegiatan ini pemberdayaan masyarakat dilakukan dalam bentuk memberikan pelatihan kepada ibu balita selam 2 hari tentang pengolahan makanan yang dilaksanakan pada tanggal $27-28$ Februari 2020 yang dihadiri 20 ibu balita atau sesuai dengan target. Kegiatan ini bertujuan agar ibu balita dapat membuat variasi pengolahan makanan secara mandiri dan mengaplikasikan produk ini pada balita sehari-hari sehingga bisa memperbaiki keadaan gizi pada balitanya.
Materi dalam pelatihan ini adalah bahan-bahan dan cara pembuatansayur sop (ayam) dengan metode pelatihan ceramah, diskusi dan simulasi (demonstrasi). Setelah pelatihan ini diharapkan ada kesinambungan dari ibu balita untuk senantiasa memberikan asupan makan seimbang yang baik dari segi kualitas maupun kuantitasnya pada balita, yang pada akhirnya bisa memperbaiki status gizi balitanya.

\section{e. Monitoring dan Evaluasi}

Kegiatan monitoring dilakukan dalam dua tahap yaitu:

\section{a. Progress Report}

Kegiatan ini dilaksanakan selama satu hari pada tanggal 29 Februari 2020 Tujuan kegiatan ini adalah untuk memberikan informasi kepada tim monitoring dalam hal tim Puskesmas (bidan) sejauh mana pelaksanaan dari kegiatan pengabdian yang telah kami lakukan dan selanjutnya melakukan perbaikan atas saran yang diberikan oleh tim monitoring. 
b. Monitoring Status Gizi Balita

Kegiatan monitoring dilakukan pada tanggal 2 Maret 2020 yang bertujuan untuk mengevaluasi status gizi dalam hal peningkatan berat badan pada balita gizi kurang yang sudah mendapatkan proses pendampingan dan pengolahan sop bagi balita.

Evaluasi dilakukan dengan membandingkan selera makan anak sebelum dan setelah pemberian produk. Monitoring dilakukan dengan menimbang balita yang sudah mendapatkan produk intervensi. Hasil penimbangan tersebut didapatkan bahwa berat badan balita sebelum dan setelah pemberian produk makanan adalah rata-rata berat badan sebelum pemberian produk adalah $12,37 \mathrm{~kg}$, dan setelah pemberian produk ratarata mengalami kenaikan sekitar $0,86 \mathrm{~kg}$ sehingga ratarata berat badan balita setelah pemberian adalah 13,23 $\mathrm{kg}$. kenaikan ini cukup signifikan karena secara teori kenaikan berat badan selama satu bulan minimal mendekati $1 \mathrm{~kg}$.

\section{KESIMPULAN}

Program pengabdian pada masyarakat dengan sasaran kader posyandu dan ibu-ibu yang mempunyai anak balita di Kelurahan Sungai Miai kota Banjarmasin adalah sebagai berikut:

a. Pengabdian telah diselenggarakan dengan baik dan berjalan dengan lancar sesuai dengan rencana kegiatan yang telah disusun, dan mendapat mendapat sambutan yang baik yang mana terbukti dengan keaktifan peserta mengikuti sejak awal acara dimulai dengan tidak meninggalkan tempat sebelum waktu pelatihan berakhir.

b. Pemberdayaan kader posyandu melalui kegiatan pelatihan kader, pembentukan kelompok peduli gizi, pendampingan oleh kader, pemberdayaan masyarakat melalui pelatihan ibu balita, monitoring dan evaluasi.

c. Mengevaluasi status gizi dalam hal peningkatan berat badan pada balita gizi kurang yang sudah mendapatkan proses pendampingan dan pengolahan sop ayam. 
d. Evaluasi dilakukan dengan membandingkan selera makan anak sebelum dan setelah pemberian produk.

\section{Saran}

Berdasarkan monitoring dan evaluasi yang telah dilakukan dapat diajukan saran sebagai berikut:

a. Adanya kegiatan lanjutan yang selalu diselenggarakan secara periodik sehinga dapat meningkatkan kemampuan, pengetahuan maupun dketerampilan kader posyandu an ibu balita dalam pengolahan menu-menu makanan guna meningkatnya selera makan balita..

b. Diharapkan kepada kader posyandu supaya gencar memberikan motivasi kepada ibu-ibu yang mempunyai balita, agar ibu balita berperan aktif dalam kegiatan posyandu guna mendapatkan informasi dan edukasi kesehatan guna memantau tumbuh kembang balita.

c. Diharapkan selalu terjalin kerjama yang berkesinambungan antara masyarakat dalam hal ini ibu balita, kader posyandu dan tim kesehatan dari Puskesmas setempat.

\section{DAFTAR PUSTAKA}

Abu, bakar, Fahmi. 2010. Menit Untuk Anakku (Buku Harian Untuk Orang Tua). PT. Elex Media Komputinda: Jakarta.

Depkes. RI 2007. Modul: Promosi Kesehatan untuk Politeknik/D3 Kesehatan. Jakarta: Pusat Promosi Kesehatan Departemen Kesehatan Republik Indonesia.

Depkes RI. 2014. Pengembangan Media Promosi Kesehatan. Jakarta: Depkes RI.

Dinas Kesehatan Kota Banjarmasin, 2017. Profil Dinas Kesehatan. Dinas Kesehatan Kota Banjarmasin.

Dinas Kesehatan Provinsi Kalimantan Selatan, 2015. Pedoman Pembinaan dan Pengembangan Usaha Kesehatan Sekolah. Banjarmasin.

Hadju, Veny dkk. 2013. Hubungan Pola Asuh Dengan Kejadian Stunting Anak Usia 6-23 Bulan Di Wilayah Pesisir Kecamatan Tallo Kota Makassar. Makassar: Ilmu Gizi Fakultas Kesehatan Masyarakat Universitas Hasanuddin Makassar dan Jurusan Gizi Politeknik Kesehatan Kemenkes Makassar, 2013 [diakses 29 Mei 2020]

Kemenkes. RI. 2011. Keputusan Menteri Kesehatan Republik Indonesia Tentang Standar Antropometri Penilaian Status Gizi Anak. Jakarta: Menkes RI

Kemenkes. RI. 2013. Riset Kesehatan Dasar (RISKESDAS) 2013. Jakarta:

Kemenkes 
Mars, Mawar. Teori H.L.Blum Derajat Kesehatan. 2014. hasmawatilaode. blogspot.com/2014/06/teorihlblum-derajat-kesehatan.html. (Online) [diakses 9 Juni 2020]

Notoatmodjo, S. Hassan Anwar, Nurlaela H. Ella, Krianto Tri, 2008, Promosi Kesehatan di Sekolah, Pusat Promosi Kesehatan Departemen Kesehatan Republik Indonesia.

Raodhah, Sitti. dkk., 2015. Pemberdayaan Pangan Lokal dalam Meningkatkan Pertumbuhan Optimal pada Masa GROWTH SPURTH Melalui Pengolahan Pangan di Pulau Lumu-Lumu Kota Makassar. http://lp2m.uinalauddin.ac.id/pengabdianmasyarakat [diakses 8 Juni 2020]

Rizal, Achmad, \& Jalpi, Agus. 2016. Peningkatan Pengetahuan Siswa dalam Memilih Makanan Jajanan di Lembaga Pendidikan
Permata Jannati Kota Banjarmasin Tahun 2016. Jurnal Pengabdian Al-Ikhlas Volume 2, No.2 April 2017). https://ojs.uniskabjm.ac.id/index.php/AIJP/article /view/782/685 [diakses 2 Juni 2020]

Rizal, Achmad, dkk., 2019. Peningkatan Keaktifan Kader Posyandu melalui Media Promosi Kesehatan dalam Mengatasi Kasus Preeklamsi Ibu Melahirkan di Kelurahan Surgi Mufti Kota Banjarmasin. Jurnal Pengabdian Al-Ikhlas, Volume 5 No. 1 (2019). https://ojs.uniskabjm.ac.id/index.php/AIJP/article /view/2373/1822 [diakses 1 Juni 2020]

Wawan, A dan Dewi M. 2010. Teori dan Pengukuran Pengetahuan, Sikap dan Perilaku Manusia. Yogyakarta:Nuha Medika.

Widyanto, C.F., \& Triwibowo, C., 2013. Trend Penyakit Saat Ini. Jakarta : CV. Trans Info Media. 